\begin{tabular}{|ccc}
\hline Sournals & $\begin{array}{c}\text { INTERNATIONAL JOURNAL OF } \\
\text { ORGANIZATIONAL LEADERSHIP }\end{array}$ & $\begin{array}{c}\text { INDUSTRIAL } \\
\text { MANAGEMENT } \\
\text { INSTITUTE }\end{array}$ \\
\hline \hline
\end{tabular}

\title{
Development and validation of instructional leadership questionnaire
}

\author{
Muhammad Akram*, Sobia Kiran, Abdurrahman İL̆̆AN \\ ${ }^{1}$ Assistant Professor, Division of Education, University of Education, Lahore, Pakistan \\ ${ }^{2}$ University of Education, Lahore, Pakistan \\ ${ }^{3}$ Associate Professor, Duzce University College of Education, Konuralp Duzce, Turkey
}

\begin{tabular}{l}
\hline \\
Keywords: \\
Instructional Leadership, \\
Visible Presence, Student \\
Progress, Feedback, \\
Curriculum Implementation \\
\hline Received \\
18 July 2016 \\
Received in revised form \\
26 October 2016 \\
Accepted \\
01 November 2016 \\
\hline
\end{tabular}

Correspondence: makram@ue.edu.pk

\begin{abstract}
The purpose of this study was to develop and validate instructional leadership questionnaire based on head teachers' perceptions of instructional leadership practices. Based on rigorous literature review of the seminal research works and models on instructional leadership, a 40 -items questionnaire grouped into seven dimensions was developed. Content validity of the questionnaire was ensured through opinions of two panels of experts and practitioners. Pilot study was conducted on 30 head teachers from rural and urban high schools to get their feedback on the language clarity, understandings, and the reliability. The alpha level of 0.75 based on pilot testing data provided validity evidence of the questionnaire. Later on, the researchers collected data from 164 head teachers, selected conveniently, from Okara and Lahore districts as Pakistan cities. Out of 164 head teacher, 85 were male and 79 were female; 78 were rural and 86 were urban; and 83 were directly selected from the selection boards while 81 were promoted to the head teacher positions. The overall internal consistency of the 40 items was 0.95 and alpha reliability of the seven dimensions ranged from 0.78 to 0.87 . Exploratory factor analysis yielded seven subscales such as instructional resource provider, maintaining visible presence, teachers' professional development, maximizing instructional time, monitoring student progress, giving feedback on teaching and learning process, and curriculum implementer. Significant positive correlations were found between all the seven dimensions of the questionnaire. Further, $t$-test for independent samples revealed that male and female, rural and urban, and selected and promoted head teachers significantly differ on the seven dimensions of the instructional leadership questionnaire, meaning that the questionnaire demonstrated variance across gender, location, and head teachers' upgradation based on selection or promotion. The findings suggested initial evidence of validity and reliability of the instructional leadership questionnaire that can be used in school settings.
\end{abstract}


Generally, instructional leadership refers to the direction, resources, and support provided by principals to the teachers and students to enhance teaching and learning (Rossouw, 1990; Tan, 2012). Instructional leadership is directing and influencing the teachers for improving and practicing the school curriculum and helps to improve and achieve objectives of the school (Murphy, 1988; Cotton, 2004). According to Heck (1992), instructional leadership consists of direct or indirect leadership activities that affect students' learning progress. It indicates recognizing directions and sharing objectives and it is also about convincing teachers for work in contributing to school achievements. Glickman, Gordon, \& Ross-Gordon (2001) defined the mixture of activities in instructional leadership which included providing direct support to teachers, curriculum development and its evaluation, development of staff, action research, and group development. Andrews and Soder (1987) additionally relate instructional tasks to the principal's responsibility to solve problems in staff development, curriculum, and in the utilization and organization of the instructional program. The concepts and definitions provide evidence that instructional leadership is a complex construct and covers a variety of variables. It is a complex and critical practice to combine the most researched and cited dimensions and verity of variables into one complete construct of instructional leadership. There is a dire need of developing a comprehensive model of instructional leadership that can best fit in national and international context. Instructional leadership is not much popular leadership type in Pakistani schools. Instructional leadership is an essential dimension in the light of facts because it focuses on the school's central activities, teaching, and learning (Chapman, 2000; Enueme \& Egwunyenga, 2008). Instructional leaders possess the basic characteristic to produce actual settings for working for effectiveness of the school (Edmonds, 1982; Marks, \& Printy, 2003). It can be generalized that instructional practices adopted by school principals depend upon the ability and knowledge about instructional tasks (Anderson 2004; Hallinger, 2003).

Current study attempted to explore the extent to which principals show their concerns and focus their attentions on improvement and learning outcomes through various instructional leadership practices. Instructional leadership represents behaviors of a school leader. The basic purpose of the study is to develop a questionnaire which will describe different dimensions of instructional leadership and could be applied extensively to the principalship. The researchers proposed a model of instructional leadership that is used in the present study for the development and validation of the instructional leadership questionnaire construct. This model may not be the entirely composite of western work of instructional leadership but it contains the dimensions of the most significant aspects of instructional leadership in Pakistani context.

\section{The Literature Review}

Hallinger and Murphy (1985) proposed instructional management model and developed Principal Instructional Management Rating Scale which consisted of three dimensions with eleven job descriptions. The school missions incorporate with formulation and communicate school goals. Managing the instructional programs focused on supervising, evaluating instruction, coordinating the curriculum, and monitoring student progress. Promoting a positive school learning climate which emphasizes on protecting the instructional time and provides incentives to teachers, promotes professional development, keeps high visibility, expands and implements academic standards, and grants incentives for learning. Sergiovanni (1984) gave 
first model of instructional leadership which consisted of five instructional leadership forces that were technical force, human force, educational force, symbolic force, and cultural force. Andrew and Soder (1987) developed 18 strategic interactions questionnaire in terms of principals in aspects of different roles as resource provider, as an instructional resource, effective communicator, and his visible presence. Weber (1987) added a model which exhibited six intelligent elements of instructional leadership as defining the schools' mission, managing curriculum and instruction, promoting a positive learning climate, observing and improving instruction, and assessing the instructional program. Whitaker (1997) developed four necessary abilities for instructional leadership as a resource provider, an instructional resource, a communicator, and visible presence.

After a careful comparison, the following seven most common dimensions for the construct of ILQ were finally selected for the instrument development; the seven domains served as the major variables of the study described as instructional resource provider, maintaining visible presence, teachers' professional development, maximizing instructional time, monitoring students' progress, feedback on teaching and learning, and curriculum implementer.

\section{Instructional Resource Provider}

Principals provide a service to teachers' fundamental instructional needs by delivering resources and materials. Principal coordinates stakeholders in achieving the school's vision and objectives and serves as an intermediary of assets such as materials (library, laboratory, and newspapers), and time and support to enable the school and its personnel to most effectively meet academic objectives (Hallinger, 2003). The instructional resources would comprise of giving the staff chances to share thoughts through staff improvement sessions, professional debates and discussions, and admitting teachers' qualities and weakness (Andrews \& Soder, 1987; Elmore, 2000). According to Waters, Marzano, and McNulty (2003), it is the responsibility of instructional leader to furnish teachers with essential equipment and professional development for the effective execution of their careers which significantly correlated with student achievement. Suitable materials for the educational curriculum program and their skillful implementation become possible through administration of effective instructional plans to support the effective curriculum instructionally (Krug, 1992; Smith \& Andrew, 1998).

\section{Maintaining Visible Presence}

The principal is physically visible in all aspects of the school (Andrews \& Soder, 1987). This dimension is consistent with maintaining visible presence to supervise and evaluate instructions. Directing and assessing guideline is characterized as exercises that include connection between the principal and school staff and students with respect to classroom enhancement (Hallinger, 1985). Successful instructional leaders need to make an obvious appearance which included concentrating on learning targets, displaying practices of learning, and outlining programs and exercises on guideline, and as an instructional leader, more than a half day spent concentrating on these destinations (Whitaker, 1997). Whitaker (1997) declared being a visible principal as one of critical qualities in the life of a school which is regularly ignored. 


\section{Teachers' Professional Development}

Principal offers and advances professional development chances to enhance teachers' instructional skills (Blase \& Blase, 2000). An effective instructional leader is a person who organizes staffs' development conferences, observation, and supervision process of staff (Maher, 1986; Zepeda, 2014). The school principal exhibits a high level of joint effort with school staff, creates continuous visits to classrooms, and provides regular criticism (Marzano, Waters, \& McNulty, 2005).

\section{Maximizing Instructional Time}

Instructional time incorporates increasing/protecting time scheduled for purposes of instruction, examinations/testing guidelines, and other student activities where direct studentteacher communication and supervision are maintained. It can be determined as the time spent by principals working directly with teachers and students to accomplish teaching and learning (Grissom \& Loeb, 2011). For protecting instructional time and time allocation for instructions, it is suggested to set up a prize framework for good participation, appropriate obligation with staff in advising parents about irregular class attendance, to hold staff meeting to talk about regular issues in instructional organizing and offer arrangements, protect classroom instructional time from disturbance, demand supervision plan, anticipate time that teachers will begin and end classes on time, utilize the full distributed time for direction, and visit classrooms to watch staff and students.

\section{Monitoring Student Progress}

Activities received by principals monitor student learning for purposes of making instructional decisions and providing feedback to students on their progress and learning achievements (Southworth, 2002). Good school principals provide teachers and parents with assessment results on an ongoing basis. General student supervision is likewise among the key obligations of the instructional leader (Memon, 2000; Yunas \& Iqbal, 2013). It mostly includes teachers in understanding different matters giving them the grade they deserve (Mangin, 2007; Nawab, 2011). Principals who demonstrate strong instructional leadership sets priority on regular classroom inspection, clear evaluation criteria, feedback on teaching learning which utilized to help staff and students to increase their performance, and frequently monitor students' improvements toward school outcomes and teacher effectiveness in obtaining learning objectives (Hallinger, 2011; Jenkins, 2009; Zepeda, 2003).

\section{Feedback on Teaching and Learning}

Principal practices include being observable throughout the school, providing praise and feedback to teachers about classroom and professional growth activities, presenting praise and feedback to students about classroom act or behaviors, and making sure of uninterrupted instructional time (Glickman, Gordon, \& Ross-Gordon, 2001). This factor in model of instructional leadership has suggested to the input on the education and learning process as facilitative principalship. It assumes that the head of the school can be regarded as instructional leader and as one of the encouraging sources for effective educating and learning (Tice, 1992; Weber, 1996). The literature stresses the exercises in which the principal ought to connect 
himself with the checking and obtaining of feedback. Following this, locating of instructional needs through talking about instructional issues, inspecting classroom learning process and giving criticism on his/her perceptions as a method for giving and empowering best instructional activities, and giving and supporting change through public and private praise are among the factors that must be taken into account.

\section{Curriculum Implementer}

The principal maintains an environment that promotes effective functioning of instructional content, arrangement, interventions, management, and monitoring in the classroom, and it is important that the principal needs to know why, how, and when to do things (Khaki, 2009; Zepeda, 2004). The real part of the instructional principal incorporates a strong educational learning action, scope of syllabus in time, and a sharp supervision (Khaki, 2009). Possibly, this is conceivable just when the instructional principal has sufficient learning, aptitudes, and expert excitement (Yunas \& Iqbal, 2013).

\section{Theoretical Framework}

This study is based on instructional theory which provides explicit guidance on how to better help people learn and succeed. Instructional theory concentrates on how to structure material for developing the education of human beings, particularly youth. In this regard, instructional leadership can assume a leader's roles in providing better help to his or her subordinate teachers so that they can learn and develop, teach effectively, maximize student learning, and increase achievement. The researchers will develop theoretical model based on the works of Hallinger and Murphy's model (1985), Sergiovanni's model (1984), Andrew and Soder's model (1987), Weber's model (1996), and Whitaker's model (1997).

This study synthesizes the major models of instructional leadership of the past two decades prevailing conceptualizations of instructional leadership and presents another conceptualization of instructional leadership to report the expectations for the future needs of coming generation. The models of instructional leadership which are used in the current study were developed through rigorous study of different instructional leadership models of Hallinger and Murphy (1985), Sergiovanni's model (1984), Andrew and Soder (1987), Weber (1996), and Whitaker (1997).

\section{Method}

The purpose of the current study was to develop and validate the Instructional Leadership Questionnaire (ILQ). The process for the development of questionnaire included defining the construct, the construction of items, and reliability analysis. Further, it involved the exploratory factor analysis for determining the construct validity of instructional leadership items.

\section{Instrument Development}

Item development depends on the scope of the dimension of the observable indicators. The definitions of the dimensions are given in defining the key terminology. Going through each quality indicator, the researchers carefully selected 44 items grouped into seven dimensions and used them to develop the questionnaire. After developing the initial 44 items and response 
scales grouped into seven dimensions, the researchers formed them into an Instructional Leadership Questionnaire (ILQ) and included demographics section in the beginning of the ILQ. The demographics comprised of several variables including principal gender, position, and location. Likert scale with five-points was developed for a response system asking principals frequency of behaviors ranging from Never (1), Rarely (2), Sometimes (3), Often (4), Always (5). Never refers to response that principal never demonstrates that instructional practice, and always refers the response that principal always demonstrates that instructional practice/ behavior.

After the development of ILQ, the researchers approached the validity by including experts' and practitioners' opinions about the content of the instrument accordingly. At this stage, two panels reviewed the pilot instrument. One expert panel comprised of five professors of education who had more than 10 years of teaching experience in public universities. This expert panel determined if the items were clear and correctly grouped into relevant dimensions and were not poorly worded. They eliminated two items that were ambiguous and were not clearly understandable. The panel agreed that the content was valid and the items measured what they were supposed to measure. The expert panel suggested a couple of changes in the layout of the ILQ to improve the readability and appropriateness. After the verification of content validity by experts, the next 42 items were reviewed by the second panel which included six practitioners (head teachers) who had instructional leader experience from 5 to 20 years. This panel determined if the items were clear or properly grouped into the factors. This group eliminated two items that seemed redundant and complex in sense. Both panels gave comprehensive opinion and feedback to develop more reliable and valid scale. After this content validity, to consider the relevance of the items to certain factors, the researchers eliminated two more items. After those modifications, the ILQ was reduced to 40 items fitted with the Pakistani context. The researchers personally visited some schools for pilot testing. The reviews led to the refinement of the instrument and minor wording changes. The reliability based on the pilot testing was high $(\alpha=.82)$ and because of the results of the pilot test, it was considered reliable to start data collection for the study.

\section{Sample}

The sample of the study included 164 head teachers selected conveniently from the two districts of Punjab, namely Lahore and Okara. Out of 164 head teachers, there were 85 (51.8\%) male and $79(48.2 \%)$ female head teachers and they were conveniently selected from rural and urban schools. So, 78 head teachers were from urban location and 86 from rural schools. Kline (2005) stated that the number of observation should not be less than 100-200 whereas Worthington and Whittaker (2006) suggested that the sample size of 150-200 are likely to be adequate with data sets containing communalities higher than 0.50 ; to this end, 164 observations of this research data can be enough for factor analyses. 


\section{Data Collection}

The data were collected in May 2015. The researchers visited 164 public high schools in two districts including Okara and Lahore, the schools which could conveniently visited by researchers. The researchers personally visited each high school, met the school head teachers and asked about their interest in the project. After the head teacher showed interest in the project, the researchers distributed a consent letter to each head teacher. The head teacher read the consent form, signed the form, and returned it to the researchers. The researchers also gave a copy of that consent form to each head teacher for their record. After the head teacher had completed the ILQ, the researchers collected the ILQ from the head teachers. No ethical issues were concerned with the study and the participants were ensured that their responses would be quite confidential and would not be shared with any higher authority. Head teachers' names and school names were not included in the demographics so that head teachers could complete the questionnaires without any fear of leaking confidentiality of the data.

\section{Results}

Thompson (2004) recommended the steps to determine the reliability and criterion-related validity of principals' responses to evaluate the adequacy of the matrix of correlations between factors and items, to extract the factors, then rotate them to examine the factor loadings, and interpret the factors. KMO and Bartlett's test were used to verify the data for appropriateness for factor analyses and whether the data were sufficient (Worthington \& Whittaker, 2006).

Cronbach's Alpha, which is the most common measure of scale reliability (Field, 2009) was calculated to measure the reliability of ILQ and the results are given in Table 1. Since the purpose was to develop an overall reliable instructional leadership instrument, the researchers calculated the internal reliability with all 40 items of the instrument. The ILQ demonstrated a relatively high level of overall Cronbach's alpha reliability $(\alpha=.95), 0.87$ for instructional resource provider ( 7 items), 0.87 for maintaining visible presences (6 items), 0.86 for professional development ( 7 items), 0.82 for instructional time ( 6 items), and 0.80 for curriculum implementation (5 items). Internal consistency interpreted as weak (0.20-0.49), medium (0.50-0.79), or high (0.80 and above) (Pett, Lackey, \& Sullivan, 2003).

Table 1 shows the reliability analysis of instructional leadership scale.

Table 1

Reliability Analysis of Instructional Leadership Scale ( $N=164$ sample) Item wise

\begin{tabular}{llccc}
\hline & Factors & \# Items & Items Included & Cronbach alpha $(\alpha)$ \\
\hline 1 & Instructional Resource Provider & 7 & $1,2,3,4,5,6,7$ & 0.87 \\
2 & Maintain Visible Presence & 6 & $8,9,10,11,12,13$ & 0.87 \\
3 & Professional Development & 7 & $14,15,16,17,18,19,20$ & 0.86 \\
4 & Maximize Instructional Time & 6 & $21,22,23,24,25,26$ & 0.82 \\
5 & Monitoring Students' Progress & 4 & $27,28,29,30$ & 0.78 \\
6 & Feedback on Teaching Learning & 5 & $31,32,33,34,35$ & 0.78 \\
7 & Curriculum Implementation & 5 & $36,37,38,39,40$ & 0.80 \\
& Overall & 40 & 40 & 0.95 \\
\hline
\end{tabular}

Note: Responses of this scale were as never (1), rarely (2), sometimes (3), often (4), and always (5). 
After the reliabilities were calculated, the relationships between the seven factors of the ILQ were also computed. The purpose of measuring the relationships between these factors was to confirm that the seven components were discriminant from each other and they avoided substantive redundancy (Messick, 1989). The results indicated that all the components of ILQ were lower to moderate the significant relationship with each other. The highest correlation was found between teachers' professional development and maximizing instructional time $(\mathrm{r}=$ $.71)$, and also between maximizing instructional time and monitoring student progress $(\mathrm{r}=.71)$. While lowest positive correlation was found between instructional resource provider and feedback on teaching and learning $(\mathrm{r}=.38)$. The summary of relationships is described in Table 2 .

Table 2

Intercorrelations of Component Measures of ILQ $(N=164)$

\begin{tabular}{|c|c|c|c|c|c|c|c|c|}
\hline & Factors & 1 & 2 & 3 & 4 & 5 & 6 & 7 \\
\hline 1 & Instructional resource provider & 1 & & & & & & \\
\hline 2 & Maintaining Visible presence & $0.53^{* *}$ & 1 & & & & & \\
\hline 3 & Teacher Professional development & $0.58^{* *}$ & $0.56^{* *}$ & 1 & & & & \\
\hline 4 & Maximizing Instructional time & $0.61^{* *}$ & $0.63^{* *}$ & $0.71^{* *}$ & 1 & & & \\
\hline 5 & Monitoring students' progress & $0.53^{* *}$ & $0.58^{* *}$ & $0.61^{* *}$ & $0.71^{* *}$ & 1 & & \\
\hline 6 & Feedback on teaching and learning & $0.38^{* *}$ & $0.44^{* *}$ & $0.42^{* *}$ & $0.41^{* *}$ & $0.39^{* *}$ & 1 & \\
\hline 7 & Curriculum Implementer & $0.68^{* *}$ & $0.53^{* *}$ & $0.70^{* *}$ & $0.63^{* *}$ & $0.53^{* *}$ & $0.42^{* *}$ & 1 \\
\hline
\end{tabular}

Note: ${ }^{*} \mathrm{p}<0.05$ (2-tailed), ${ }^{*} \mathrm{p}<0.01$ (2-tailed)

The researchers computed 40 items for pairwise combinations. It determined that the calculated matrix of correlations was suitable for factor analysis according to Bartlett's test of Sphericity, 3807.086, $d f=780, \mathrm{p}<0.000$. Bartlett's test of sphericity indicated highly significance and a Kaiser-Meyer-Olkin measure of sampling adequacy was $\mathrm{KMO}=0.89$. The KMO statistics varies between 0 and 1 (Field, 2009) that KMO values between 0.5 and 0.7 are mediocre, values between 0.7 and 0.8 are good, values between 0.8 and 0.9 are great whereas values above 0.9 are superb (Hutcheson \& Sofroniou, 1999). Forty components had Eigenvalues over Kaiser's (1974) criteria of 1 and in combination described $62 \%$ of the variance. These results of sampling adequacy and multivariate normality indicated good quality of matrix.

Principal Component Analysis was run to explore the factor loadings and seven factors were found. This process runs for attesting the stability of the seven factors and items loading on the factors with similar patterns. The results of Varimax, a method of orthogonal rotation (Field, 2009), solution of factor loadings from the PCA are described in Table 3. It is interpreted that all items in each factors touched the criterion of loading at least 0.40 on their particular factor (Tabachnick \& Fidell, 1996). 
Table 3

Factor Loadings $(N=164)$

\begin{tabular}{|c|c|c|c|c|c|c|c|}
\hline \multicolumn{8}{|c|}{ Rotated Component Matrix } \\
\hline \multirow[t]{2}{*}{ As an instructional leader, $\mathrm{I} / \mathrm{my}$} & \multicolumn{7}{|c|}{ Component } \\
\hline & 1 & 2 & 3 & 4 & 5 & 6 & 7 \\
\hline Encourage teachers to use instructional materials freely. & .744 & .077 & .030 & .099 & 062 & .079 & .257 \\
\hline Organize and deliver the instructional materials to teachers. & 685 & .246 & .113 & .161 & .161 & .086 & .103 \\
\hline Students have sufficient access to the instructional materials. & 670 & .179 & .319 & .333 & -.171 & .059 & -.042 \\
\hline Teachers have sufficient access to instructional material. & .669 & .186 & .250 & .022 & .091 & .127 & .001 \\
\hline Recommend resources in areas in which teachers need. & 644 & .088 & .149 & .265 & .084 & .078 & .184 \\
\hline Guide teachers in using instructional resources. & 640 & .258 & .218 & -.014 & .409 & -.006 & .075 \\
\hline Take feedback on availability of the instructional resources. & .572 & .156 & .067 & .093 & .226 & .073 & .243 \\
\hline Visit classes regularly to observe teaching and learning. & .181 & .827 & .070 & .170 & .050 & .152 & -.007 \\
\hline Physically available for instructional issues. & .223 & .744 & .127 & -.076 & .247 & -.016 & .060 \\
\hline Personally attend co-curricular activities of the school. & .225 & .713 & .112 & .203 & 029 & .222 & .159 \\
\hline Conduct meetings to discuss instructional matters. & .139 & .652 & .211 & .181 & .021 & .134 & .167 \\
\hline Discuss with teachers the matters related to the instruction. & .191 & .621 & .142 & .180 & .417 & .101 & -.092 \\
\hline Visibly present in school for teachers and students. & .074 & .585 & .198 & .316 & .239 & .099 & .134 \\
\hline Available for teachers' professional development. & .111 & .105 & .718 & .246 & .066 & .035 & .251 \\
\hline Plan faculty meetings for professional development. & .253 & .137 & .680 & .000 & .170 & .230 & .033 \\
\hline Arrange teachers' meetings to help them grow professionally. & .126 & .301 & .626 & .306 & .254 & -.009 & .186 \\
\hline Develop follow up plans for assessing professional development. & .155 & .167 & .606 & .123 & -.171 & .248 & .384 \\
\hline Encourage teachers to take steps to solve instructional issues. & .169 & .156 & .574 & .207 & .385 & .056 & -.086 \\
\hline Encourage teachers to improve their classroom practices. & .198 & .201 & .456 & .172 & 415 & .015 & .279 \\
\hline Plan professional development opportunities according to needs. & .169 & .202 & .425 & .247 & 411 & .028 & .201 \\
\hline Ensure that all students are present in the class during class time. & .212 & .205 & .482 & .605 & .060 & .108 & .003 \\
\hline Protect classroom instructional time from outside interruptions. & .234 & .216 & .148 & .582 & .096 & .102 & .165 \\
\hline Encourage all teachers to come to class well-prepared and in time. & .296 & .140 & .304 & .546 & .282 & -.041 & .102 \\
\hline Use class time of teachers for regular meetings. & .112 & .246 & .402 & .532 & 315 & .138 & -.196 \\
\hline Make sure that students are not allowing to office during class. & .083 & .381 & .200 & .437 & .240 & -.035 & .219 \\
\hline Solve issues related to discipline to maximize instructional time. & .401 & .106 & -.025 & .434 & .328 & .120 & .335 \\
\hline Meet teachers individually to discuss student progress issues. & .121 & .167 & .208 & .038 & .760 & .192 & -.002 \\
\hline Discuss students' results with teachers for curricular strengths. & .161 & .076 & .015 & .314 & .646 & .212 & .040 \\
\hline Review students' work when evaluating classroom instruction. & .082 & .277 & .135 & .509 & .510 & .094 & .202 \\
\hline Ask the teachers to send the students' progress reports to parents. & .349 & .243 & .242 & .363 & .433 & .025 & .139 \\
\hline Provide public praise to those teachers who perform well. & .010 & .053 & .062 & -.152 & .196 & .819 & .076 \\
\hline Reinforce the teachers in staff meetings/newsletters/memos. & .068 & -.026 & .210 & .057 & .063 & .713 & -.166 \\
\hline Praise outstanding students on their achievement publically. & .042 & .163 & -.046 & .280 & .125 & .673 & .234 \\
\hline Communicate students' performance in parent teacher meetings. & .223 & .278 & .014 & .029 & .093 & .667 & .233 \\
\hline Provide verbal and written feedback to my teachers. & .158 & .367 & .297 & .214 & -.096 & .493 & .080 \\
\hline Ensure that teachers teach the required curriculum. & .303 & .057 & .146 & .087 & -.048 & .217 & .541 \\
\hline Encourage a lesson plan for making curriculum effective. & .358 & .191 & .338 & .241 & .274 & .090 & .523 \\
\hline Encourage my teachers to engage their students in activities. & .292 & .382 & .313 & .235 & 138 & -.077 & .491 \\
\hline Meet teachers to get reports about curriculum implementation. & .345 & .261 & .392 & -.113 & .257 & .023 & .468 \\
\hline Students' marks provide info about curriculum implementation. & .309 & -.014 & .419 & .193 & 057 & .272 & .452 \\
\hline
\end{tabular}

Note: (factor loadings $=>.30$ Loadings less than 0.40 were eliminated.

Principal component analysis (Jollifle, 2002) was performed using the varimax rotation method for factor extraction on the items. PCA uses eigenvalues which represent the proportion of variance accounted for by the factors. The eigenvalues greater than 1 showed that there were 7 factors that represented $62 \%$ of the variance which is considered good. Instructional resource provider explained $35.95 \%$, maintaining visible presence $5.81 \%$, professional development $5.61 \%$, maximize instructional time $4.75 \%$, monitoring students' progress $4.15 \%$, feedback on teaching learning 3.08\%, and curriculum implementer $2.83 \%$ variance. The results are presented in Table 4. 
Table 4

Eigenvalue, percentage of variance, and Cronbach's coefficient alpha for each factor

\begin{tabular}{lcccc}
\hline Factors & Eigenvalue & \% of variance & Cumulative \% & $(\alpha)$ \\
\hline Factor 1 & 14.381 & 35.953 & 35.953 & .87 \\
Factor 2 & 2.326 & 5.814 & 41.768 & .87 \\
Factor 3 & 2.247 & 5.617 & 47.384 & .86 \\
Factor 4 & 1.902 & 4.754 & 52.138 & .82 \\
Factor 5 & 1.663 & 4.157 & 56.295 & .78 \\
Factor 6 & 1.236 & 3.089 & 59.384 & .78 \\
Factor 7 & 1.133 & 2.833 & 62.217 & .80 \\
\hline
\end{tabular}

Note: $\%=$ percentage; $(\alpha)=$ Cronbach alpha

In the current study a scree plot was used for factor analysis, data loading retention/ extraction of factors. A scree plot suggests the eigenvalues (greater than 1) associated with a factor in descending order against the number of factor. Stevens (2002) suggested that with a sample of more than 200 participants, the scree plot provides a fairly reliable criterion for factor selection. Kaiser (1960) recommend retaining all factors with eigenvalues greater than 1 . Figure 1 illustrates the scree plot which showed that the plot starts with the eighth factor; therefore, seven factors should be reserved. The scree plot sustained total seven-factor resolution obtained using the Kaiser-Guttman rule.

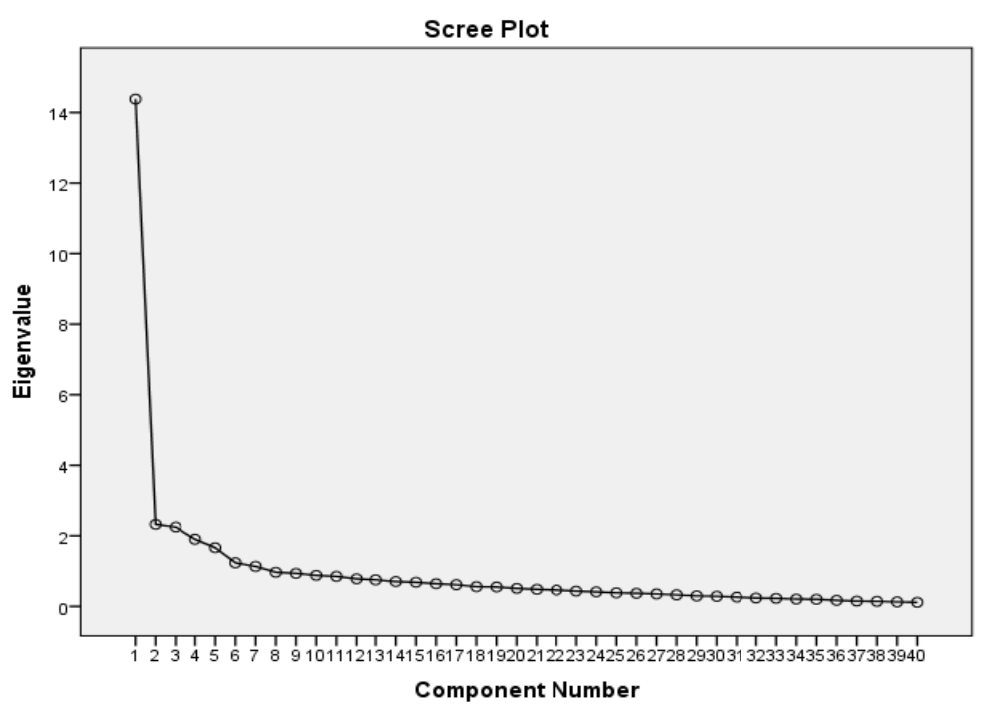

Figure 1. Scree plot showing the extraction of factors

Further, three analyses were conducted based on demographic variables. Therefore, $t$-test for independent samples revealed that male and female, rural and urban, and selected and promoted head teachers significantly differ on the seven dimensions of the instructional leadership questionnaire, meaning that the questionnaire demonstrated variance across gender, location, and head teachers' upgradation based on selection or promotion. The following results were found on the basis of these analyses. Table 5 displays the $t$-test results that compare instructional leadership behaviors of principals in terms of gender.

\section{Confirmatory Factor Analyses}

Path diagram demonstrates the relations between items and factors regarding the seven dimensions' model of the Instructional Leadership scale. The regression coefficient called a 
"factor loading" or ( = Lambda) in structural equation models provide a measure of the strength of relationship between an item and latent variable. When a group of items "load" on a given factor, the estimated coefficients help us to better understand the latent variable being modeled (Edwards, Wirth, Houts, \& Xi, 2012). All the factor loadings (see Table 5) were statistically and significantly different from zero and have expected sign, that is, positive factor loadings (Schumacker \& Lomax, 2010). Error variance ranged between 0.30 and 0.78 as supposed to be acceptable level whereas items' factor loadings ranged between 0.46 and 0.84 could be supposed in high level (see Table 5). The $t$-values of items which present those tvalues of whole items were significant.

Table 5

Path Diagram and T-Test Results of Instructional Leadership Model / Scale

\begin{tabular}{|c|c|c|c|c|}
\hline \multirow[b]{2}{*}{ ILQ Dimensions } & \multicolumn{2}{|c|}{ Path Diagram Results } & \multicolumn{2}{|c|}{ T-test Results } \\
\hline & $\begin{array}{l}\text { Factor Loadings } \\
\text { Ranged Between }\end{array}$ & $\begin{array}{c}\text { Relationship Between } \\
\text { Dimensions of ILQ } \\
\text { and ILQ }\end{array}$ & $\begin{array}{c}\text { T Values Ranged } \\
\text { Between }\end{array}$ & $\begin{array}{c}\mathrm{T} \text { Values Between } \\
\text { Dimensions of ILQ } \\
\text { and ILQ }\end{array}$ \\
\hline 1.Instructional Resource Provider & $.63-.78$ & .79 & $7.35-8.69$ & 8.08 \\
\hline 2. Maintain Visible Presence & $.68-.80$ & .75 & $8.99-10.80$ & 8.79 \\
\hline 3.Professional Development & $.62-.80$ & .90 & $7.34-9.42$ & 9.02 \\
\hline 4.Maximizing Instructional Time & $.60-.73$ & .94 & $7.27-8.75$ & 9.81 \\
\hline 5.Monitoring Student Progress & $.62-.77$ & .88 & $6.71-7.98$ & 7.97 \\
\hline 6.Feedback on Teaching Learning & $.56-.76$ & .53 & $6.36-8.98$ & 5.40 \\
\hline 7.Curriculum Implementer & $.46-.84$ & .88 & $5.32-5.90$ & 5.69 \\
\hline
\end{tabular}

Fit indices related to model were given in Table 6.

Table 6

Fit Indices of Instructional Leadership Model / Scale

\begin{tabular}{cc}
\hline Fit Indices & Values \\
\hline $\mathrm{X}^{2}$ & 1267,77 \\
$\mathrm{Df}$ & 733 \\
$\mathrm{X}^{2} / \mathrm{df}$ & 1,73 \\
$\mathrm{p}$-Value & 0,00 \\
RMSEA (Root Mean Square Error of Approximation) & 0,067 \\
NFI (Normed Fit Index) & 0.92 \\
NNFI (Non-Normed Fit Index) & 0.96 \\
RMR (Root Mean Square Residual) & 0.062 \\
GFI (Goodness of Fit Index) & 0.72 \\
AGFI (Adjusted Goodness of Fit Index) & 0.69 \\
CFI (Comparative Fit Index) & 0.96 \\
\hline
\end{tabular}

According to CFA results (see Table 6) of instructional leadership scale, it was found that $\chi^{2}$ $=1267.77$ and $\mathrm{df}=733$. One of the model fit indexes was $\chi^{2} / \mathrm{sd}$ (Marsh, Balla \& McDonald, 1988 ) and this was 4.14 based on the DFA results. Kline (2005) suggested that for large samples, $\chi^{2} /$ sd ratio that was less than 1.73 corresponded to excellent fit and $\chi^{2} /$ sd ratio that was less than 5 corresponded to intermediate level fit. According to this, the 1.73 value was a superb result for the model, and $\chi^{2}$ value responded to the sample (West, Taylor, $\& \mathrm{Wu}, 2012$ ); so, other fit indices could be examined as well. When other fit indices were examined, the root mean square error of approximation (RMSEA) that is given in the path diagram was 0.067 in acceptable fit (Marsh, Hau, \&Wen, 2004), and the root mean square residual (RMR) was 0.062 in acceptable number (McDonald \& Moon-Ho, 2002). As the fit indices were further 
examined, it was found that the goodness of fit index (GFI) was 0.72 and the adjusted goodness of fit index (AGFI) was 0.69. Because a good fit requires a number greater than 0.90 for GFI and AGFI indices (West et al., 2012), the model's 0.72 and .69 values in this study indicated a weak fit. For models' other fit indices, the normed fit index (NFI) was 0.92; the non-normed fit index (NNFI) was .96; and the comparative fit index (CFI) was .96. It can be concluded that these values were the indicators of a sufficient fit (Hu \& Bentler, 1995).

Table 7 presents the $t$-test for independent samples based on head teacher gender.

Table 7

T-test for Independent Samples based on Head Teacher Gender

\begin{tabular}{|c|c|c|c|c|c|}
\hline Variable & Gender & Mean & $\mathrm{SD}$ & $\mathrm{t}$ & sig. \\
\hline \multirow{2}{*}{ Instructional Resource Provider } & Male & 30.50 & 4.44 & \multirow{2}{*}{2.864} & \multirow{2}{*}{0.005} \\
\hline & Female & 28.26 & 5.54 & & \\
\hline \multirow{2}{*}{ Maintain Visible Presence } & Male & 27.97 & 2.95 & \multirow{2}{*}{3.401} & \multirow{2}{*}{0.001} \\
\hline & Female & 26.08 & 4.10 & & \\
\hline \multirow{2}{*}{ Professional Development } & Male & 31.61 & 3.93 & \multirow{2}{*}{3.171} & \multirow{2}{*}{0.002} \\
\hline & Female & 29.29 & 5.37 & & \\
\hline \multirow{2}{*}{ Maximizing Instructional Time } & Male & 27.57 & 3.18 & \multirow{2}{*}{2.905} & \multirow{2}{*}{0.004} \\
\hline & Female & 25.89 & 4.17 & & \\
\hline \multirow{2}{*}{ Monitoring Student Progress } & Male & 18.78 & 1.98 & \multirow{2}{*}{2.990} & \multirow{2}{*}{0.003} \\
\hline & Female & 17.72 & 2.56 & & \\
\hline \multirow{2}{*}{ Feedback on Teaching Learning } & Male & 17.00 & 3.03 & \multirow{2}{*}{0.918} & \multirow{2}{*}{0.360} \\
\hline & Female & 16.56 & 2.95 & & \\
\hline \multirow{2}{*}{ Curriculum Implementer } & Male & 22.67 & 2.61 & \multirow{2}{*}{2.61} & \multirow{2}{*}{0.001} \\
\hline & Female & 20.83 & 3.94 & & \\
\hline
\end{tabular}

Note: (Significant 2 tailed**)

The results of Table 7 showed that male and female head teachers perceived the instructional leadership factors in quite different way and were significant at an alpha of 0.05 expect for dimension of feedback on teaching and learning $t(2,162)=.918, p=.360$ indicated insignificant differences. Results also revealed that male principals had perception that displayed instructional leadership behavior in comparison with female principals. Table 8 displays $t$-test for independent samples based on head teacher position.

Table 8

T-test for Independent Samples based on Head Teacher Position

\begin{tabular}{|c|c|c|c|c|c|}
\hline Variable & Gender & Mean & SD & $\mathrm{t}$ & sig. \\
\hline \multirow{2}{*}{ Instructional Resource Provider } & Selected & 30.43 & 4.46 & \multirow{2}{*}{2.597} & \multirow{2}{*}{0.010} \\
\hline & Prompted & 28.39 & 5.54 & & \\
\hline \multirow{2}{*}{ Maintain Visible Presence } & Selected & 27.96 & 2.98 & \multirow{2}{*}{3.264} & \multirow{2}{*}{0.001} \\
\hline & Prompted & 26.14 & 4.06 & & \\
\hline \multirow{2}{*}{ Professional Development } & Selected & 31.56 & 3.96 & \multirow{2}{*}{2.957} & \multirow{2}{*}{0.004} \\
\hline & Prompted & 29.39 & 5.34 & & \\
\hline \multirow{2}{*}{ Maximizing Instructional Time } & Selected & 27.55 & 3.22 & \multirow{2}{*}{2.750} & \multirow{2}{*}{0.007} \\
\hline & Prompted & 25.96 & 4.13 & & \\
\hline \multirow{2}{*}{ Monitoring Student Progress } & Selected & 18.77 & 2.00 & \multirow{2}{*}{2.812} & \multirow{2}{*}{0.006} \\
\hline & Prompted & 17.76 & 2.55 & & \\
\hline \multirow{2}{*}{ Feedback on Teaching Learning } & Selected & 16.96 & 3.06 & \multirow{2}{*}{.739} & \multirow{2}{*}{0.461} \\
\hline & Prompted & 16.61 & 2.93 & & \\
\hline \multirow{2}{*}{ Curriculum Implementer } & Selected & 22.65 & 2.63 & \multirow{2}{*}{3.362} & \multirow{2}{*}{0.001} \\
\hline & Prompted & 20.90 & 3.91 & & \\
\hline
\end{tabular}

Note: Significant 2 tailed. $* *$ 
The results of Table 8 showed that selected and promoted head teachers perceived the instructional leadership factors in quite different way and were significant at an alpha of 0.05 expect for dimension of feedback on teaching learning $t(2,162)=.739, p=.461$. Results showed that as a type of assigning to post, selected principals had perception that displayed instructional leadership behavior in comparison with promoted principals. Table 9 display $t$-test results that compare instructional leadership behaviors of principals in terms of location of their school.

Table 9

T-test for Independent samples based on Head Teacher Location

\begin{tabular}{|c|c|c|c|c|c|}
\hline Variable & Gender & Mean & SD & $\mathrm{t}$ & sig. \\
\hline \multirow{2}{*}{ Instructional Resource Provider } & Rural & 30.61 & 4.39 & \multirow{2}{*}{2.898} & \multirow{2}{*}{0.004} \\
\hline & Urban & 28.34 & 5.49 & & \\
\hline \multirow{2}{*}{ Maintain Visible Presence } & Rural & 27.96 & 3.03 & \multirow{2}{*}{3.051} & \multirow{2}{*}{0.003} \\
\hline & Urban & 26.25 & 4.00 & & \\
\hline \multirow{2}{*}{ Professional Development } & Rural & 31.74 & 3.70 & \multirow{2}{*}{3.260} & \multirow{2}{*}{0.001} \\
\hline & Urban & 29.36 & 5.40 & & \\
\hline \multirow{2}{*}{ Maximizing Instructional Time } & Rural & 27.62 & 3.22 & \multirow{2}{*}{2.835} & \multirow{2}{*}{0.005} \\
\hline & Urban & 25.98 & 4.08 & & \\
\hline \multirow{2}{*}{ Monitoring Student Progress } & Rural & 18.94 & 1.65 & \multirow{2}{*}{3.649} & \multirow{2}{*}{0.000} \\
\hline & Urban & 17.66 & 2.68 & & \\
\hline \multirow{2}{*}{ Feedback on Teaching Learning } & Rural & 16.92 & 3.13 & \multirow{2}{*}{.529} & \multirow{2}{*}{0.598} \\
\hline & Urban & 16.67 & 2.88 & & \\
\hline \multirow{2}{*}{ Curriculum Implementer } & Rural & 22.79 & 2.52 & \multirow{2}{*}{3.718} & \multirow{2}{*}{0.000} \\
\hline & Urban & 20.87 & 3.88 & & \\
\hline
\end{tabular}

(Significant2 tailed. *)

According to Table 9, the results revealed that urban and rural head teachers perceived the instructional leadership factors in quite different way and the results were found biased to $t(2,162)=.529, p=.598$ for feedback on teaching learning. In other words, principals who their school located in rural had perception that displayed instructional leadership behavior in comparison with principals whose schools located in urban.

\section{Discussion and Conclusion}

In instructional leadership the principals perform a vital role in determining students' effective learning (Heck, 1992) to improve the classroom directions and instructions (Whitaker, 1997). The more extensive perspective represented those principals where the quality of teaching and learning were strong and were considered as effective factors and demonstrated instructional leadership both directly and indirectly (Murphy, 1988). In Pakistani perspective the school head teachers are considered as instructional leaders but there was not such instrument which can evaluate the instructional leadership practices demonstrated by head teachers in their local context. The current research supposed to contribute to this gap. The researchers thoroughly delved into the international standard of instructional leadership literature and developed seven categories to find a valid and a reliable principals' instructional evaluation instrument based on the Pakistani context. This instrument contains comprehensive instructional leadership dimensions which would help principals to get basic knowledge about instructional leadership to enhance their instructional skill and provide the guidance. Following this, it can play a 
significant role in helping education researchers and principals to promote instructional knowledge to increase school effectiveness and learning outcomes. Descriptive statistics considered the results which can be interpreted as principals and had perception that they displayed instructional leadership behaviors in a highly manner. It is supposed that Pakistani principals had sufficient instructional leadership competencies. ILQ considered 'monitoring student progress' as the dimension that principals displayed most whereas 'feedback on teaching learning' was least. This ILQ is more effective because each item in this instrument present a clear understanding about instructional activities in Pakistani context. This study was a significant one since it established the overall validity and reliability of the Instructional Leadership Questionnaire with Pakistani school principals and recommended improvements in scales for evaluating dimensions of instructional leadership practices because previous research carried out with western context. In future, by administrating this instrument, principals would be able to understand if they can demonstrate such instructional practices as effective principals.

\section{References}

Anderson, K. (2004). The nature of teacher leadership in schools as reciprocal influence between teacher leaders and principals. School Effectiveness \& School Improvement, 15(1), 97-113.

Andrews, R., \& Soder, R. (1987). Principals instructional leadership and school achievement. Instructional Leadership, 44, 911.

Blase, J., \& Blase, J. (2000). Effective instructional leadership: Teachers' perspectives on how principals promote teaching and learning in schools. Journal of Educational Administration, 38(2), 130-141.

Chapman, D. W. (2000). Trends in educational administration in developing Asia. Educational Administration Quarterly, 36 (2), 283-308.

Cotton, K. (2004). Principals and student achievement. What the Research Says, 88(639), 92-95.

Edmonds, R. R. (1982). Programs of school improvement: An overview. Educational Leadership, 40(3), 8-11.

Edwards, M., C., Wirth, R. J., Houts, C. R. \& Xi, N. (2012). Categorical data in the structural equation modeling framework. In R. H. Hoyle (Eds.), Handbook of structural equation modeling (pp. 263-276). New York: The Guilford Press.

Elmore, R. F. (2000). Building a new structure for school leadership. Washington, DC: Albert Shanker Institute.

Enueme, C. P., \& Egwunyenga, E. J. (2008). Principals' instructional leadership roles and effect on teachers' job performance: A case study of secondary schools in Asaba Metropolis, Delta State, Nigeria. Journal of Social Science, 16(1), 13-17.

Field, A. (2009). Discovering statistics using SPSS. ( $3^{\text {rd }}$ ed.). Los Angles, CA: Sage Publication.

Finley, M. J. (2014). An exploration of the relationship between teachers' perceptions of principals' instructional leadership and transformational leadership behaviors (Unpublished doctoral dissertation). Georgia: Georgia Southern University.

Glickman, C., Gordon, S., \& Ross-Gordon, J. (2001). Supervision and instructional leadership: A developmental approach (5 $5^{\text {th }}$ ed.). Needham Heights, MA: Allyn and Bacon.

Grissom, J. A., \& Loeb, S. (2011). Triangulating principal effectiveness: How perspectives of parents, teachers, and assistant principals identify the central importance of managerial skills. American Educational Research Journal, 48(5), 1091-1123.

Hallinger, P. (2003). Leading educational change: Reflections on the practice of instructional and transformational leadership. Cambridge Journal of Education, 33(3), 329-352.

Hallinger, P. (2011). Leadership for learning: Lessons from 40 years of empirical research. Journal of Educational Administration, 49(2), 125-142.

Hallinger, P., \& Murphy, J. (1985). Assessing the instructional management behavior of principals. Elementary School Journal, 86(2), 217-247.

Heck, R. H. (1992). Principals' instructional leadership and school performance: Implications for policy development. Educational Evaluation and Policy Analysis, 14(1), 21-34. 
Hu, L. T., \& Bentler, P. M. (1995). Evaluating model fit. In R. H. Hoyle (Eds.), Structural equation modeling: Concepts, issues, and applications (pp. 76-99). Thousand Oaks, CA: Sage.

Hutcheson, G., \& Sofroniou, N. (1999). The multivariate social scientist: Introductory statistics using generalized linear linear models. London: Sage Publication.

Jenkins, B. (2009). What it takes to be an instructional leader. Principal, 88(3), 34-37.

Jollifle, I. T. (2002). Principal component analyses. New York: Springer.

Kaiser, H. F. (1960). The application of electronic computers to factor analyses. Educational \& Psychological Measurement, 20, 141-151.

Kaiser, H. F. (1974). An index of factorial simplicity. Psychometrika, 39(1), 31-36.

Khaki, J. E. A. (2009). Leading leaders: A school leadership development experience in Pakistan. The Sindh University Journal of Education, 38, 18-32.

Kline, R. B. (2005). Principles and practice of structural equation modeling ( $2^{\text {nd }}$ ed.). New York: Guilford.

Kleine-Kracht, P. (1993). Indirect instructional leadership: An administrator's choice. Education Administration Quarterly, 29(2), 187-212.

Krug, S. E. (1992). Instructional leadership: A constructivist perspective. Educational Administration Quarterly, 28(3), 430443.

Maher, C. A. (1986). Improving the instructional supervisory behavior of public school principals by means of time management: Experimental evaluation and social validation. Professional School Psychology, 1(3), 177-191.

Mangin, M. M. (2007). Facilitating elementary principal's support for instructional teacher leadership. Educational Administration Quarterly, 43(3), 319-357.

Marks, H. M., \& Printy, S. M. (2003). Principal leadership and school performance: An integration of transformational and instructional leadership. Educational Administration Quarterly, 39(3), 370-397.

Marsh, H. W., Balla, J. R., \& McDonald, R. P. (1988). Goodness-of-fit indexes in confirmatory factor analysis: The effect of sample size. Psychological Bulletin, 103, 391-410.

Marsh, H. W., Hau, K. T., \& Wen, Z. (2004). In search of golden rules: Comment on hypothesis testing approaches to setting cutoff values for fit indexes and dangers in overgeneralizing Hu and Bentler's (1999) findings. Structural Equation Modeling, 11, 320-341.

Marzano, R. J., Waters, T., \& McNulty, B. A. (2005). School leadership that works: From research to results. Alexandria, VA: Association for Supervision and Curriculum Development.

McDonald, R. P., \& Moon-Ho, R. H. (2002). Principles and practice in reporting structural equation analyses. Psychological Methods, 75(2), 420-435.

Memon, M. (2000). Re-conceptualizing the role of head teachers as pedagogical leaders in Pakistan: Implication for policy reforms. Education, 3(12), 6-10.

Messick, S. (1989). Validity. In R. L. Linn (Ed.), Educational measurement (3 ${ }^{\text {rd }}$ ed.) (pp. 13-103). New York: Macmillan.

Murphy, J. (1988). Methodological, measurement, and conceptual problems in the study of instructional leadership. Educational Evaluation \& Policy Analysis, 10(2), 117-139.

Nawab, A. (2011). Exploring leadership practices in rural context of a developing country. International Journal of Academic Research in Business and Social Sciences, 1(3), 181-189.

Pett, M., Lackey, N. \& Sullivan, J. (2003). Making sense of factor analysis. Thousand Oaks: Sage Publications, Inc.

Rossouw, L. F. (1990). The Principalship: Dimensions in Instructional Leadership. Prentice-Hall, Inc.

Schumacker, R. E., \& Lomax, R. G. (2010). A beginner's guide to: Structural equation modeling (3 ${ }^{\text {rd }}$ ed.). New York: Routledge Taylor \& Francis Group.

Sergiovanni, T. J. (1984). Leadership and excellence in schooling. Educational Leadership, 41(5), 4-13.

Smith, W. \& Andrews, R. (1989). Instructional leadership: How principals make a difference. Alexandria, VA: Association for Supervision and Curriculum Development.

Southworth, G. (2002). Instructional leadership in schools: Reflections and empirical evidence. School Leadership \& Management, 22(1), 73-91.

Stevens, J. P. (2002). Applied multivariate statistics for the social sciences $\left(4^{\text {th }}\right.$ ed.). Hillsdale, NJ: Erbaum.

Tabachnick, B. G., \& Fidell, L. S. (1996). Using multivariate statistics ( $3^{\text {rd }}$ ed.). New York: HarperCollins College Publishers. 
Tan, C. Y. (2012). Instructional leadership: Toward a contextualized knowledge creation model. School Leadership \& Management, 32(2), 183-194.

Tice, T. N. (1992). Instructional leaders again. Educational Digest, 57(9), 32-38.

Thompson, B. (2004). Exploratory and confirmatory factor analysis: Understanding concepts and applications. Washington, DC, American Psychological Association.

Waters, J. T., Marzano, R. J., \& McNulty, B. A. (2003). Balanced leadership: What 30 of research tells us about the effect of leadership on student achievement. Aurora, CO: Mid-Continent Research for Education and Learning.

Weber, J. (1996). Leading the instructional program. In S. Smith \& P. Piele (Eds.), School leadership (pp. 253-278). Eugene, OR: Clearinghouse of Educational Management.

West, S., G., Taylor, A. A., \& Wu, W. (2012). Model fit and model selection in structural equation modeling. In R. H. Hoyle (Eds.), Handbook of structural equation modeling (pp. 209-231). New York: The Guilford Press.

Whitaker, B. (1997). Instructional leadership and principal visibility. The Clearinghouse, 70(3), 155-156.

Worthington, R.L., \& Whittaker, T.A. (2006). Scale development research: A content analysis and recommendations for best practices. The Counseling Psychologist, 34(6), 806-838.

Yunas, M., \& Iqbal, M. (2013). Dimensions of instructional leadership role of principal. Interdisciplinary Journal of Contemporary Research in Business, 4(10), 629-637.

Zepeda, S. J. (2003). Instructional Supervision: Applying Tools and Concepts. Larchmont, NY: Eye on Education.

Zepeda, S. J. (2004). Instructional Leadership for School Improvement. NY: Eye on Education.

Zepeda, S. J. (2014). The principal as instructional leader: A handbook for supervisors. New York: Routledge. 